Jeremy Scott

4,300 words

School of European Culture and Languages

Cornwallis NW

University of Kent

Canterbury CT2 7NF

07972239452

J.D.Scott@kent.ac.uk

The Fetch

by Jeremy Scott 
Fetch (n.): the supernatural fac-simile of some individual, which comes to ensure to its original a happy longevity, or dissolution; if seen in the morning, the one event is predicted; if in the evening, the other.

Oxford English Dictionary

Down the end of the car park by the river, where the path forks right and leads into town, turn left. Then you'll find it, next to the antique shop which is never open, past the pub where the fires are always on.

That's where it is.

If we walk too quickly we'll miss it, and most people do. Like us, they're moving too fast. Their minds are elsewhere (shopping, food, parking tickets, the smile on a face going in the other direction). But the house is indifferent. Condemned, empty, but somehow still standing behind its veil of dark bushes and the rotting apple tree, under the shadow of the cathedral, it sits tight. In the overgrown garden there's an old fridge (never hide in fridges in case they shut and suffocate you), a supermarket trolley, a tea chest, flower pots on their sides with crowns of moss and, of course, the wrought-iron gate with the fat rusty padlock and chain.

There are stories gathering here. Like moths around a deadlight, it's hard to see them from the outside.

Fathers tell daughters of the black-eyed long-snouted dog that skulks in the dark of the garden and only appears at the gate when the cathedral bells strike three in the morning.

Others tell of coming closer to look through the railings, hoping to catch sight of the flash of his teeth. Another tale tells us of the fate of one of the house's former occupants (in some versions, the dog's master), a quiet clerk of the cathedral who was found late one night hanged from a rafter by a rope woven over many months from the unpicked threads of tapestries. People say he had offended God in dark and unspeakable ways. Yet another has a gipsy watercress seller (sometimes a young woman, sometimes an old man) who hides one raw winter night for shelter in the house's cellar. The master of the house hears low singing and goes down, throwing the gypsy out into the snow. Later that night, part of the house (the part where the master lies sleeping) burns to the ground. Now, if you go and stand outside the house when the moon is bright, you can see a grey someone, something, standing framed in one of the windows of that re-built wing. As you look again, your heart ka-booming in your throat, you see that the thing in the window is hammering on the glass, its mouth a taut 'o'.

And daughters drift away into troubled sleep, fathers having passed on their own, much-cherished disquietude.

And then there's the story we'll tell, almost certainly true, about the boy who fell from the branches of the old apple tree in the garden and snapped his neck like a shard of unripe fruit. 
Stories gather here. Lives gather here, you see, doubling and propagating like time and mirrors. Like moths around a deadlight, you can only see them from the outside.

\#

Slowly, surely, because her own father had suddenly left her life, this particular daughter, Molly, the hero of this particular story, found the house filling the newlydug holes in her mind. She and the house, both abandoned, needed one another.

The house and the memory of her father belonged together. At one time she found it hard to think of one without thinking about the other, and this made her sad. She remembered her father being helped up the stairs by her mother. Before, there'd have been barking voices dampened only slightly by the floorboards of her bedroom, grandma's voice cutting in sometimes, plaintive. Molly would lie on the floor, ear pressed to the carpet. The creaking of the stairs and the sound of shuffling feet, whispered quarrelling voices, was the cue for her to jump back into bed. Her mother's final shouted word, the slamming of her parents' bedroom door, her mother retreating quickly back downstairs. Molly would wait for what sometimes happened. It happened more and more often towards the end.

Her parents' bedroom door would creak open again, and unsteady footsteps would move along the landing. Then Molly would open the door of her room to see her father, staring at the house from the landing window - that familiar view, the spires of the cathedral, beyond in the distance the hospital chimney like an upside-down cigarette, and there, to the left, blurring everything else, the frame of the house with its fraying gables.

Once or twice, her father would hear the door open and turn around to look. She would try to smile, but the look on his face would stop her.

And so, afterwards, on those now-empty weekend mornings, or before school, she would ride towards the house on her bike, but only a very small part of the way. She would always stop at the end of the road, like she'd been told to, before the concrete morphed into black tar macadam. She'd play the games, though. In her mind. The one where you run up to the house's gate while your friends look on, jump as if you're about to climb over it, then turn and run away. Or the braver one, played by bigger boys, where you squeeze through the railings and run to touch the front door. Then, you run back. You run like you will never ever run again in your life, the back of your head tingling, arms flailing, legs pumping, convinced that grey hands are about to grab the hem of your t-shirt.

The house drew the daughter like stale cheese draws a mouse. She stood at the landing window and watched it, mouldering at the border of her shrinking, emptying world. 
Here's what happened. Story time. The beginning of one. Or its end. It's hard to say.

Molly loved her dad's stories. The one about Molly and her little brown bear that went on and on, night after night. The adventures they had! Molly and her bear travelled everywhere on a magic ship called 'The Silver Bird', crewed by mice and with a white duck as its captain. Captain Duck had a knapsack on his back and carried a shiny brass telescope. Molly lied that she couldn't get to sleep without hearing a story. Dad would sit on the bed with that soothing smell of soap and horseradish, smile, and then begin. 'What happened last time?' he'd ask. And Molly would tell, and dad would pick it up, and the journeys would begin again.

On that night, though, something was different. Dad was quiet. His eyes were puffy, like clouds. There was the smell of something else. Something bitter. Molly waited.

Dad looked at the wall over Molly's head, saying nothing. Molly tried to remember other stories he'd told her. The one about two fish, one golden, one blue, who had a race across the tank where they lived. The blue one lost. There was a point, but she couldn't remember it. Or the one about the teddy bear who sat in the dark feeling the shapes and bumps in his Christmas stocking, trying to guess what each present was before pulling it out. Or the one about the father and son who lived in a caravan at the edge of a wood where birds waited to be shot by hunters. Later, afterwards, Molly would see herself walking with father through those very woods; the crunch of leaves, the feel of bark, the smell of mushrooms.

And the fear of the gamekeeper on the lookout for poachers, hiding behind a black tree trunk. No matter how hard she tried for it not to happen (screwing her eyes up tight worked for a while) the wood would always end eventually. You could feel it coming; just over the next hill, the trees would thin and then disappear. And there, instead of the brightly-painted caravan with its smoking chimney, crouched the house. She saw herself there, alone.

Dad sat still while the shadows rose and fell across his face with the cars passing outside. Eventually, he sighed and said: 'The house has ghosts.'

Molly saw the landing light go on under the door and heard the creaking of floorboards as mum came out of the bedroom. The creaking stopped outside her bedroom door. Dad waited. Then, the creaking started up again as mum carried on down the hall to the bathroom.

'Sometimes, it's better just to stare them down,' Dad continued. She wanted to say, 'What house?'

Instead, she said: 'Stare down the ghosts?'

Dad nodded, then fell silent again. Molly waited again. 
'Me and my best friend Joe Peel,' said Dad eventually, 'decided to break into the house. For a bet, you see. Another boy said we wouldn't have the guts to go in there at night. So Joe said "yes" then, quick as you like. If Joe said "yes" to something, I had to say "yes" too.'

The toilet flushed.

'We agreed to meet by the river as soon as it got dark. I had to climb out the window at the back of the house, crawl across the roof of the lavatory and climb down the cherry tree, quiet as a mouse so as not to wake up granny and grandpa. Then, I got on my old bike and cycled down to the river to meet Joe. When I got down there, Joe was already waiting, sitting with his back against a tree and smoking tea in his dad's old pipe. I could barely see him in the gloom. "Are you chicken?" he said. I said no. "Well, come on then, you chicken," he said. And we went to the house.'

Dad cleared his throat again. He was looking at the backs of his hands stretched out in front of him. Molly watched them trembling. Dad looked up again with his clouds-for-eyes and carried on telling.

'It seemed to take forever to get to the front gate. We could see it, just, a way off in the distance in the dark, but it never got any closer. In the end, though, we arrived. The gate wasn't locked in those days. Not like it is now. But for some reason we couldn't get it open.'

Mum's footsteps came down the landing again and stopped outside the door. Dad waited. The footsteps carried on, away. A door shut.

'We tried flicking the latch, pushing it up with sticks, shaking the gate - nothing worked. Eventually, we decided to slip through the railings. We started walking towards the door. A dog barked then. It seemed far away to me, but to Joe it was there with us in the garden. He didn't like dogs. They terrified him. He screamed, for real this time. I kept shushing Joe, scared we might wake someone up. He shot straight up the old apple tree, straight up like a squirrel. The dog was still barking away, growling too, the sounds getting closer. But I didn't stop. I just kept going towards the door. As soon as I got there, I pulled it open. I could still hear Joe shouting at me to come back. But I wasn't scared - not of the dog. Who's chicken now, I thought? The light coming in through the open door showed the floor and the foot of the stairs. And the smell. Old and dusty. The place was full of dust and not much else.'

Now. We probably want to hear about white sheets draped over furniture. And cobwebs in the corners of the room. Or the scratching of rats coming from shadows. But there was nothing like that. The door didn't even creak when Molly's father opened it. There was nothing much to see. Just a doorway like a hole. And Molly's father walked through it and onwards towards the stairs.

'I wasn't scared,' said dad. 'I thought I would be, but I wasn't. I was thinking about Joe, still hiding up in that tree. I could hear him shouting my name. So I shouted his name back at him. He didn't reply. He went silent. It was strange. I felt calm. The 
fear comes before, not during. Never once you're there.'

Dad was staring at the wall behind Molly's head again. His cheekbones were wet. She didn't understand.

She looked at dad's face. His eyes wouldn't find hers. She wondered whether the story was finished. Perhaps the rest was for another time, and this was the end for now. Or maybe this was the real end. The End. Nothing else had happened. Dad had turned around and gone home for his tea. He'd been inside the house and that was enough to win the bet. They could have brought the other boy back something from inside the house to prove they' $d$ been inside; a candlestick, maybe, or a painting from the wall, or an old brick from the garden? Or maybe kids just believed each other in those days no matter what; Grandma and Molly's mum were always going on about the good-old-days after all. Tomorrow was Saturday. She could go and see her best friend Sam. Do races in the park. Molly waited for her dad to bend forward, kiss the top of her head, switch off the bedside light and stand lingering in the doorway looking back for a few moments like he always did.

How sad he seemed now. So sad.

But we want to know what happened to poor Joe Peel, watching from the branches of the apple tree as Molly's father (just a little boy then, of course) goes in to the house on his own, creeping up the garden path and pushing open the door. One last look back over his shoulder, then over the doorstep and in, leaving the door open behind him. The little boy in the apple tree just watches and waits. What else can he do? The dog is howling up at him, eyes reflecting stars, it seemed, from its post amongst the roots of the trees. Joe Peel can't climb down. It's getting darker now. The sun has long gone and there's no moon.

And Joe Peel waits. He waits and watches, while the black mouth of the doorway fades and fades from view, then disappears altogether. And still no one comes out.

Suddenly, the branch that he sits on cracks, once. Then it snaps.

\section{And imagine.}

Inside the house, the little boy summons up courage like he has never managed before. He walks forwards across wooden boards that he can hear but not see, one tiny step at a time. The door swings shut behind him and he stops. He stands, frozen, eyes trying to adjust to darkness so solid that it presses against his skin. Things gradually come into view. The crack in the wall. The chair, upturned. The picture hung askew on a wooden panel. And there, at the top of the half-collapsed stairs, afloat, he sees the Fetch, Joe Peel's grey-white double, blank, without expression, with one arm hanging by its side, the other crossing its body to grip at the base of the neck. Joe Peel's Fetch looks through him to the door at his back, and out to the broken apple tree where the real Joe Peel lies still on the black grass. 
The light went on again out in the hall. The footsteps creaked back. 'Molly?' Her mother's voice.

Dad bent forward, kissed Molly's forehead and went to the door, pushing it open with his foot. The shape of her mum loomed behind. Mum said something, cross. Dad hissed back.

'Is that the end?' Molly asked.

Dad stood in the doorway. He raised his right arm once, palm forwards. Then he switched off the light and the door swung shut behind him.

He was gone.

$$
\text { \# }
$$

And so, afterwards, Molly would look out from the landing window, looking back. She found it harder and harder to remember the time before. Her father, and how he made her feel. She would ask mum to explain why, but mum would say 'Not now, not yet', standing there in her nightdress that grew tattier and dirtier day by day, while grandma pretended to busy herself at the sink or hob but would keep looking over at her daughter to watch her flail and fade.

Other things went on as usual. School days. Summer days on shingle beaches with dogs, sleepovers at Sam's house, kites, seaweed, mud. Darker days where time was a slow shuffle and rain and tree branches would thrash the glass of her window. Days got longer, then shorter again. Then they stretched once more until they reached Molly, still standing at the landing window, still staring across the shiny rooftops.

\#

With light leaking around the edge of the curtains, Molly woke up.

She opened the curtains and looked for the house. There it was, a smudge in the bottom right of the windowpane. A crow was standing on the chimney pot. It turned his head to look at her and opened its beak. But Molly didn't catch what it said, if it said anything, because her mother's voice had chosen that moment to flutter up the stairs.

'Sam's here!'

Molly pulled on jeans and t-shirt and went downstairs. She had already decided. This would be the day.

Sam was already sitting at the kitchen worktop in his green goalie top, scuffed shoes swinging beneath the pine stool. He looked up with a milk moustache as Molly walked in. Sam sipped his milk while Molly ate Frosties. Her mother stood at the sink, clasping and unclasping her hands.

With breakfast done, Molly and Sam got up and headed for the door which lead to the garage. 
Behind that door, two bikes, one red, one blue, leaned, poised, against the unused tool rack and the drawers of screws and nails which now gathered orange dust from the corrugated iron roof. Molly's nerves tingled as she swung her leg over the blue one, put her foot on the pedal and pushed off from the wall of the garage. The slight incline of the concrete floor took her under the up-and-over door and down onto the road, where Sam waited on the red one, the sun low but rising over his right shoulder like the opening shot of a cowboy film. Molly came to a shuddering stop next to Sam, the bike's rear wheel swinging to the right in a skid.

'The house,' said Molly.

'OK,' said Sam. 'Are you sure?' 'I don't want to,' said Molly. 'Chicken.'

Molly's mouth was a thin line.

Off they go, then. Sam in the lead, Molly bringing up the rear. Molly looked into the light from low sun now appearing above clouds and saw the house, beyond the margins, an old grey toad squinting over the tops of trees.

\section{\#}

So Molly and Sam hurtled away to hunt for the end of the story, riding side by side to the top of the cul-de-sac where Molly lived.

At the top of Molly's road they stopped. The bikes' front tyres just touched the jaggy line where the road turned from creamy-coloured to black-and-grey. Molly wanted to spend the rest of the day out here, just where they were, at the end of the world. But Sam, not even looking back, was already crossing the border.

Molly followed.

Along the road they went, then turned right down the footpath which led to the river. Standing up in the saddles, they crossed the football field mud (watch out for quicksand), then over the wooden river bridge that makes rat-a-tatting noises as you crossed (go slowly in case you wake the troll), and then stopped, Sam in front, Molly behind.

The house lay across the car park, its chimney like a black finger. Behind that, the cathedral, very far away. The morning was getting darker with the promise of rain.

Molly walked the bike forwards, wobbling slightly, until she was at the front. She felt Sam's eyes on her, waiting. She was in charge now. It didn't feel like it, though. She thought about turning around and heading back. Maybe spend the day fishing under umbrellas, listening to the rain patter and feeling safe. Make sandwiches to take, a flask of hot chocolate, Wagon Wheels too, maybe. She turned around to say it. Sam's head was on one side, his eyes narrowed, his old-fashioned green goalie top damp around the chest and armpits.

'Molly?'

Molly lowered her head. Her hands gripped the bike's handlebars until her knuckles were white. She thought of her father. She saw a shape, a presence in her bedroom doorway. But then, just the house.

'Molly?'

She bit her lip. Her left plimsoll pushed down onto the left pedal. The first spatter 
of rain tapped on her forehead.

The pedal moved and she was off and flying in the direction of the house. Bigger drops of rain began to fall, and water dribbled down her forehead and into her eyes. She blinked it away. Sam shouted 'wait', then followed.

Sam came up over the rise to see that Molly was already there at the gate.

Surely it was too early in the day for ghosts.

At long last, Molly stood, under the dead apple tree with the missing branch, never regrown, in the garden of the house.

Molly walked slowly up the weed-choked path. She didn't need to turn to see Sam rattling the gate, then squeezing through the railings, then standing stock-still underneath the grey tree. Nothing to be done. Whatever it was that was going to happen was already happening.

Molly passed the old fridge with its door grimly ajar, stepped over the remains of the mouldering cardboard box and ignored the bent-up supermarket trolley. Of course, there was no black dog. The blue door with the peeling paint was in front of her. It was swinging open like a mouth. She stepped over the threshold and into the house, to stand still in the square of light at the foot of stairs. The door swung half-shut behind her.

And there, at the top of the stairs, afloat, there: the Fetch, looking back at her, left arm hanging by his side, the other crossing his body to grip at the bicep.

But he was smiling.

Molly thought of red kites, their tails trapped and wrapped in the branches of grey trees. She saw homemade toy boats skimming across the surfaces of ponds on commons, blue sails, self-steering. She saw the white of greasy paper around fish and chips. Small bottles of Coke inside used moneybags. She heard the sound of scratched $45 \mathrm{~s}$ through floorboards and the whispered jokes through the crack in a bedroom door. She smelled curry paste and burned popadoms and the smoke from wet leaves on the garden bonfire. She felt the pressure on the quilt at the end of her bed in the night, and felt it disappear again at the story's unwanted ending. She felt the jostle of men in overcoats and the roar of the crowd. Like the kite, she felt the unwrap, unlock and lift away and the edge of escape.

She looked up at the Fetch at the top of the stairs. The light was brightening again outside as the rain clouds edged away. The Fetch raised its right arm once, palm forwards. It smiled again. As if to say 'see?'

Molly heard the door opening and Sam's voice from behind: 'Molly?' Slowly, the 
Fetch faded and was gone.

So you see: the fear comes before, not during. Never once you're there.

\#

And Molly's mother stands one evening outside her daughter's open bedroom door, looking in at her back as she sits at the scuffed wooden desk. Before, she would have been silent, perhaps colouring in a book with blunt pencils that skidded over the borderlines, or staring from the window with the fingers of her left hand clawing at her earlobe. Silent. What are you doing, Molly? Nothing.

But now. The desk has been moved from the window and placed on the other side of the room. A wooden-framed mirror hangs on the wall above the desk. The colouring books have gone.

'Hello, mum.'

'What are you writing?' 'Just stuff.'

Molly would look up.

And if the day is bright, as now it often seems to be, then sunlight will bend through the window, warm the edges of the room and light up the mirror in which Molly's reflection looks back at us to smile.

Jeremy Scott

School of European Culture and Languages

Cornwallis NW

University of Kent

Canterbury CT2 7NF

jeremy-scott.co.uk

J.D.Scott@kent.ac.uk

@jeremy_d_scott

\section{Bio}

I write, I teach and I research on the border between literature and language studies at the University of Kent (and sometimes at home). My interests are broad, but if I had to boil them down I'd be left with: fictional technique, literary representations of dialect (an aspect of fictional technique), the relationship between narratives and identity, Nordic literature and culture, stylistics-based approaches to creative writing (fictional technique again) and creativity in general. I also like world-building. As 
well as my own fiction, I have published on contemporary British and Irish fiction, on literary stylistics, travel literature and innovative perspectives on creative practice.

\section{Published fiction}

'Black Shuck (or God's Windows)', in New Writing. 11(2). 2014. London: Routledge. 168-181.

'Eucharist: or the Lark Ascending', in New Writing. 11(2). 2010. London: Routledge. 107-122.

'The Gloaming', in Stand Magazine. 9(1). 2009.

'An Isolated Place' in Connections (April 2002)

'The Mourning' and 'Juggler Comes Dancing', in Voices (Belfast: The Gallery Press 2000)

'Mixed Blooms', in Westland Row: a collection of new writing. Dublin: Imp Press. 1998 